HELICOBACTER PYLORI

\title{
Effect of Th1 cytokines on acid secretion in pharmacologically characterised mouse gastric glands
}

\section{T Padol, R H Hunt}

Gut 2004;53:1075-1081. doi: 10.1136/gut.2003.026435

See end of article for authors' affiliations

.....................

Correspondence to: Dr R H Hunt, Department of Gastroenterology, McMaster University Health Sciences Centre, Room 4W8, 1200 Main St West, Hamilton, Ontario L8N 3Z5, Canada; huntr@mcmaster.ca

Accepted for publication 30 January 2004
Background and aims: Acid secretion plays an important role in the ecology of Helicobacter species and acid secretory status heralds patterns of gastritis. The presence of inflammatory cells and their products, in close proximity to parietal cells, questions the extent of the effect of cytokines on acid secretion.

Methods: We adopted and extensively characterised the mouse gastric gland preparation and its secretory capacity, which was measured using ${ }^{14} \mathrm{C}$-aminopyrine accumulation. Subsequently, we tested the secretory properties of a wide range of species specific cytokines, including those associated with Th 1 and Th2 immune responses.

Results: ${ }^{14} \mathrm{C}$-aminopyrine accumulation in mouse gastric glands was shown to be a very sensitive "in vitro" method of testing classical secretagogues and antisecretory compounds, and provided pharmacological data on acid secretion in the mouse. Only two mouse cytokines, interleukin 2 and interferon $\gamma$, had a direct effect on acid secretion causing dose dependent inhibition.

Conclusions: Both cytokines belong to the Thl type immune response and consequently their inhibitory effect may play a role in the hyposecretion seen with $\mathrm{H}$ pylori infection and colonisation throughout the corpus of the stomach that potentially can lead to gastric atrophy and subsequently, in some cases, cancer.
$\mathrm{H}$ elicobacter pylori plays a pathogenic role in humans and also in animal models. Bacterial factors and the host response are both implicated in the extent of gastric inflammation. ${ }^{1}$ The status of acid secretion plays a pivotal role in Helicobacter ecology and contributes to the mucosal abnormalities. ${ }^{2-4}$ Bacterial metabolites and secretory products can directly or indirectly modulate the function of parietal cells. $^{5}$ A number of reports suggest that the net effect on acid secretion evoked by the presence of $H$ pylori can be either inhibitory or stimulatory. ${ }^{6}$ Enhanced or impaired acid secretion leads respectively to either duodenal ulcer or gastric atrophy which may subsequently predispose to gastric cancer. ${ }^{67}$ Not only bacterial factors but also the host specific immune response determines the severity of gastric inflammation. ${ }^{8}$ Evidently, the host immune response can modulate the secretory properties of parietal cells and we postulate that Helicobacter induced hypochlorhydria may be linked to the effect of cytokines released by the particular type of immune response. Mouse models of Helicobacter induced gastritis have recently entered the mainstream of research in this area and have been useful in prioritising factors responsible for the pathogenesis of disease. ${ }^{9}{ }^{10}$ For that reason we have adopted and characterised the "in vitro" mouse model of acid secretion using gastric glands. We believe that this method is essential for testing acid related hypotheses and complements the results obtained from the standardised mouse model of Helicobacter induced gastritis. Moreover, the mouse gastric gland preparation enables us to test a variety of cytokines and other immunochemical products available only in the mouse system, which eliminates any cross species related concerns in the interpretation of results. A number of reports have presented somewhat conflicting results in this area that warranted further validation in the mouse system, in particular, to test the action of mouse cytokines on mouse parietal cells for a possible direct mechanism of action.

The mouse model of Helicobacter induced gastritis resembles some of the features of gastritis in humans, and many of the recent findings on the mechanisms involved in this infection come from this particular animal model, thus creating a niche in which the "in vitro" mouse model of acid secretion can answer some of the questions that were previously only suggested by interpolation. The knowledge generated from the experiments performed on gastric glands or parietal cells obtained from dogs, rabbits, guinea pigs, and rats may not reveal the dynamics and consequences of Helicobacter related infection observed in vivo, as these species failed to host reliable models. It has been shown, using the mouse model of Helicobacter infection, that mouse strain specificity exists, ${ }^{8}$ and this suggests involvement of a genetic component in the aetiology of gastric disease. Depending on the strain of mouse, the type of immune response to Helicobacter infection varies, being either predominantly Thl or Th2. ${ }^{1}$ This complements the fact that genetic factors also play a role in disease in humans as not all those infected with virulent strains of $H$ pylori become symptomatic.

As a wide array of anti- and proinflammatory cytokines can be evoked by the host immune response, we decided to test the effects of several of these on acid secretion. The list of mouse cytokines tested representing the Thl response were: interferon (IFN) $\gamma$, interleukin (IL)-2, and IL-12, and representing the Th2 response: IL-4, IL-6, and IL-10. Tumour necrosis factor $\alpha($ TNF- $\alpha)$ and IL-1 $\beta$ were chosen to reconfirm their effect in mouse parietal cells, as previously demonstrated in other species. IL-8 was chosen for its involvement in $H$ pylori infection. There are limited data on gastric acid secretion in the mouse gastric gland model from our own work ${ }^{11}$ and that of Hinkle and colleagues, who studied gastrin deficient mice. ${ }^{12}$ In this report, we present the results of our studies of Th1 and Th2 cytokines in a mouse gastric gland model, which we first characterised pharmacologically.

Abbreviations: $A P,\left[{ }^{14} \mathrm{C}\right]$-aminopyrine; IL, interleukin; IFN, interferon; $T N F$, tumour necrosis factor; $\mathrm{PGE}_{2}$, prostaglandin $\mathrm{E}_{2} ; \mathrm{BSA}$, bovine serum albumin; PBS, phosphate buffered saline; PEA, piridylethylamine; $R-\alpha-$ MH, R- $\alpha$-methylhistamine; $p$-FHHSDiF, fluorohexahydrosiladifenidol; LPS, lipopolysaccharide 


\section{MATERIALS AND METHODS}

\section{Animals}

Female Balb/c mice, 6-8 weeks old, were obtained from Charles River Canada (St Constant, Quebec, Canada) and kept under standard housing conditions: temperature 21$23^{\circ} \mathrm{C}$, humidity $40-50 \%, 12 / 12$ hour light/dark cycle, and fed Purina Lab Rodent Chow for up to 12 weeks. Ten mice for each acid assay were fasted for 24 hours (water ad libitum) and killed by cervical dislocation. The stomachs were quickly removed, opened along the lesser curvature, and placed in oxygenated $37^{\circ} \mathrm{C}$ phosphate buffered saline (PBS) buffer at $\mathrm{pH}$ 7.3. Use of animals was approved by the Animal Research Ethics Board at McMaster University.

\section{Preparation of gastric glands from mice}

The gastric gland preparation was performed according to the method of Berglindh, ${ }^{13}$ with some modifications. Briefly, the gastric mucosa was scraped off underlying muscle using a scalpel blade, pooled, and washed twice (approximately $200 \times \mathrm{g}$ for five minutes) in PBS. Scrapings of the gastric mucosa were placed in an enzyme solution that contained $2 \mathrm{mg} / \mathrm{ml}$ of glucose, $1 \mathrm{mg} / \mathrm{ml}$ of bovine serum albumin (BSA, Sigma A-7888, St Louis, Missouri, USA), $0.25 \mathrm{mg} / \mathrm{ml}$ of type II-s soybean trypsin inhibitor ( Sigma T-9128), and $0.23 \mathrm{mg} / \mathrm{ml}$ of type IV collagenase (Sigma C-5138). Different batches of collagenase were screened as there was a discrepancy in the acid producing capacity of gland preparations depending on the batch of collagenase used. The collagenase that resulted in a gland preparation that gave the highest aminopyrine incorporation and therefore indicated intact secretory function was used in subsequent experiments. The mouse gastric mucosa was enzymatically digested at $37^{\circ} \mathrm{C}$ for 45 minutes in a flat bottom covered $150 \mathrm{ml}$ Erlenmeyer flask and agitated by a magnetic stirrer (approximately $100 \mathrm{rpms} / \mathrm{min}$ ). After enzymatic digestion, the gastric glands were passed through a nylon mesh ( $500 \mu \mathrm{m}$; Small Parts Inc, Florida, USA) to separate debris and undigested remains of the gastric mucosa. The preparation was then washed three times (approximately $200 \times \mathrm{g}$ for five minutes) in enzymatic buffer that contained neither collagenase nor trypsin inhibitor. Finally, the preparation was resuspended in $50 \mathrm{ml}$ of incubation medium containing $2 \mathrm{mg} / \mathrm{ml}$ of BSA, $2 \mathrm{mg} / \mathrm{ml}$ of glucose, $1 \mathrm{mM} \mathrm{MgSO}_{4}$, and a total of $2 \mathrm{mM}$ of $\mathrm{CaCl}_{2}$. Therefore, the yield of this preparation was $50 \mathrm{ml}$ with approximately $10 \mu \mathrm{l}$ of packed gastric glands per $\mathrm{ml}$, which translated to $0.356 \pm 0.054 \mathrm{mg} / \mathrm{ml}$ of protein, as measured by the Biorad method using BSA as the standard.

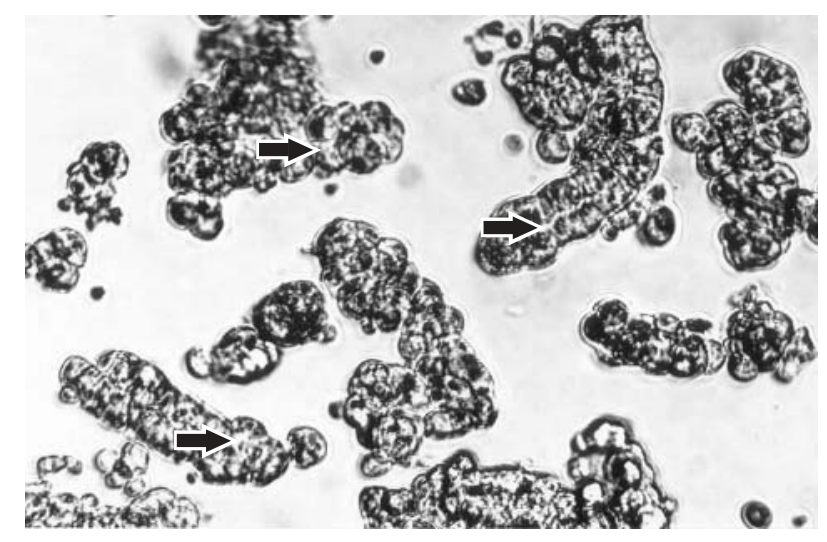

Figure 1 Photograph showing preparation of mouse gastric glands. Arrows indicate luminal canal inside the gland surrounded by bulging parietal cells $(400 \times$ magnification).

\section{Measurement of acid secretion in the mouse gastric} glands

Acid secretion was measured by accumulation of weak base $\left[{ }^{14} \mathrm{C}\right]$-aminopyrine (AP), as also described by Berglindh, ${ }^{13}$ with some modifications. Briefly, the experiment was carried out in closed $1.5 \mathrm{ml}$ Eppendorf tubes containing $0.5 \mathrm{ml}$ of resuspended gastric glands with added secretagogue (carbachol $0.01 \mathrm{mM}$ or histamine $0.1 \mathrm{mM}$ ), antisecretory compound (for example, somatostatin or prostaglandin $\mathrm{E}_{2}$ $\left.\left(\mathrm{PGE}_{2}\right)\right)$, and doses of the test cytokine. Tubes testing basal acid secretion did not contain histamine or carbachol. Also, $20 \mu \mathrm{l}$, equivalent to $0.25 \mu \mathrm{Ci}$ of AP (Amersham Pharmacia Biotech, Baie, D'urfé, Québec, Canada; specific activity $115 \mathrm{mCi} / \mathrm{mmol}$ ) was added to the tubes and incubation was carried out at $37^{\circ} \mathrm{C}$ for 60 minutes with rotation. Therefore, all tested reagents, including AP, were added at the same time and coincubated with the gastric glands. Tubes were spun at approximately $1500 \mathrm{~g}$ for five minutes, the supernatant aspirated, and the pellet washed three times in incubation buffer to minimise non-specific AP retention in the glands. The pellet was transferred to scintillation tubes and solubilised with $1 \mathrm{ml}$ of tissue solubiliser (NCS-2; Amersham) overnight. The next day, $50 \mu \mathrm{l}$ of glacial acetic acid was added to each tube containing the solubilised pellet in order to neutralise the highly basic tissue solubiliser. Pellets were counted in a Beckman scintillation counter LS 5801 after addition of $5 \mathrm{ml}$ of scintillation fluid (ACS; Amersham). Radioactivity accumulated by glands with $0.1 \mathrm{mM}$ of dinitrophenol was subtracted from all data to compensate for non-specifically trapped AP, which accounted for less than $0.5 \%$ of the maximal histamine response. Each sample was tested in triplicate within each individual experiment. Each experiment was repeated in different gland preparations and this repetition is expressed by the n number of individual experiments.

\section{Chemicals}

Cytokines were purchased from the following sources: mouse IFN- $\gamma$ (Upstate Biotechnology Inc, Lake Placid, New York, USA), mouse IL- $1 \beta$, mouse IL-2 (Genzyme), mouse IL-4, mouse IL-6 (Upstate Biotechnology Inc), human IL-8 (Upstate Biotechnology Inc), mouse IL-12 (R\&D Systems), mouse TNF- $\alpha$ (R\&D Systems, Minneapolis, Minnesota, USA), monoclonal rat antimouse IFN- $\gamma$, IgGl (Upstate Biotechnology Inc), purified rat myeloma IgGl (Zymed Laboratories Inc, San Francisco, California, USA), dibutyryl cyclic AMP $\left(\mathrm{N}^{6}, 2^{\prime}\right.$-o-dibutyryladenosine $3^{\prime}: 5^{\prime}$-cyclic monophosphate, D-0627; Sigma), PEA (piridylethylamine was a gift from Dr ME Parsons through Dr PK Rangachari), $p$ FHHSDiF ( $p$-fluorohexahydrosiladifenidol, $\mathrm{M}_{3}$ selective antagonist; RBI/Sigma, Canada), AFDX-116 ( $\mathrm{M}_{2}$ selective antagonist, a gift from Dr Karl Thomae through Dr PK Rangachari $),{ }^{14}$ pirenzepine $\left(M_{1}\right.$ selective antagonist; $\mathrm{RBI} /$ Sigma), SCH28080 (substituted pyridyl $(1,2 \alpha)$ imidazole, $\mathrm{K}^{+}$ site inhibitor of the gastric $\left(\mathrm{H}^{+}+\mathrm{K}^{+}\right)$ATPase, a gift from Schering-Plough Research Institute (New Jersey, USA). ${ }^{15}$ All chemicals were of the highest purity and were purchased from Sigma, unless otherwise stated. Most compounds were dissolved in water or water based buffers with the exception of compounds dissolved in DMSO such as: $\mathrm{PGE}_{2}$ at $10^{-2} \mathrm{M}$, pentagastrin at $10^{-1} \mathrm{M}, \mathrm{A} 23185$ at $10^{-2} \mathrm{M}$, thapsisgargin $10^{-2} \mathrm{M}$, forskolin at $10^{-2} \mathrm{M}$, and SCH28080 at $2 \times 10^{-2} \mathrm{M}$. Omeprazole was dissolved in water at $2 \times 10^{-2} \mathrm{M}$ with addition of $0.6 \mathrm{mg}$ of $\mathrm{NaHCO}_{3} / \mathrm{ml}$.

\section{Statistical analysis}

Data were calculated as percentage of the maximal response to various stimulants of AP uptake, and $\mathrm{n}$ represents the number of gland preparations for which each data point was 

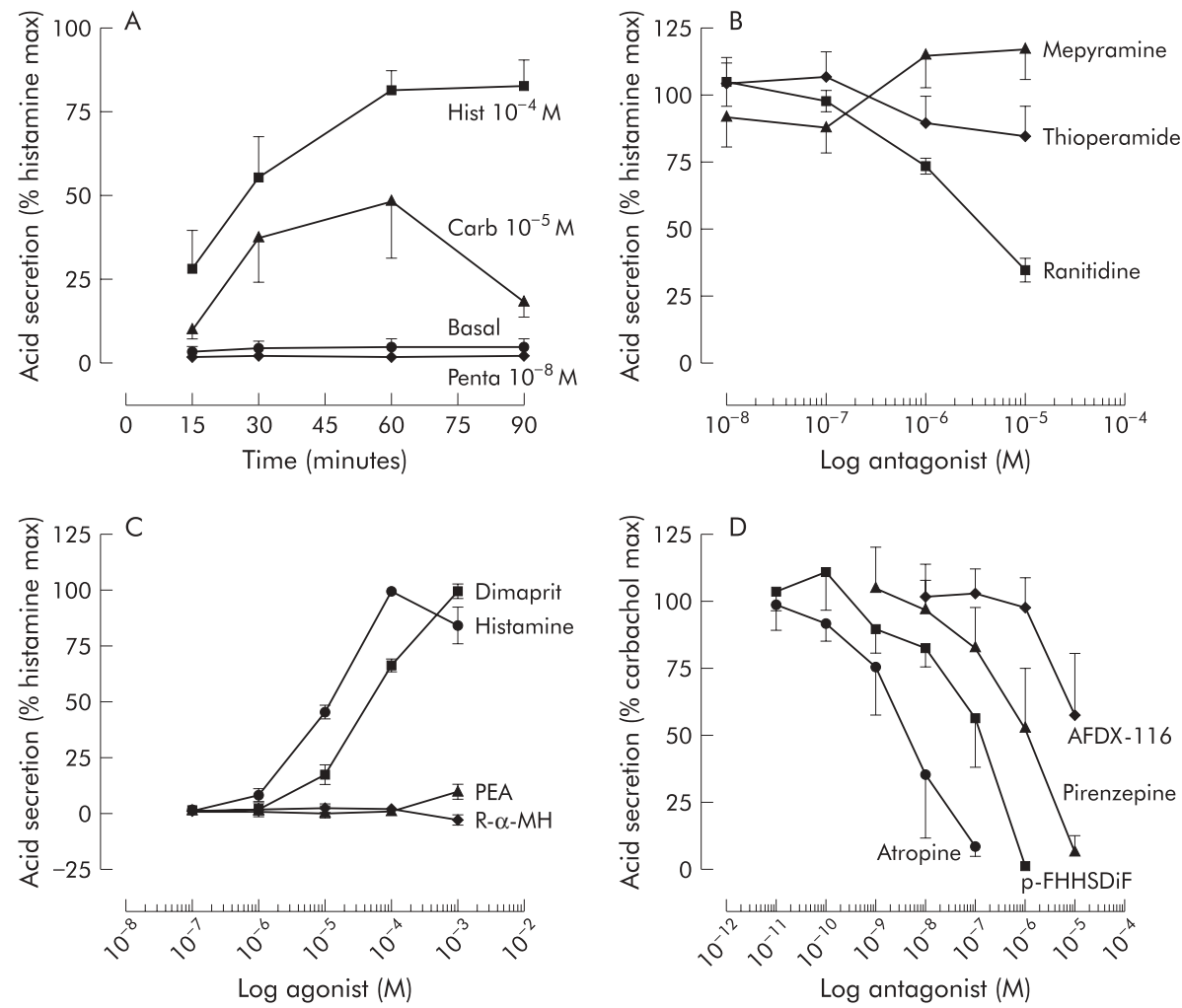

Figure 2 (A) Effect of incubation time on basal and secretagogue stimulated acid secretion, as measured by $\left[{ }^{14} \mathrm{C}\right]$ aminopyrine accumulation in mouse gastric glands $(n=3)$. Hist, histamine; Carb, carbachol. (B) Effect of antagonists on maximal acid output (100\%) induced by $0.1 \mathrm{M}$ of histamine

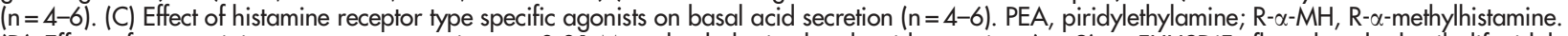
(D) Effect of muscarinic receptor antagonists on $0.01 \mathrm{M}$ carbachol stimulated acid secretion $(n=3)$. p-FHHSDiF, fluorohexahydrosiladifenidol.

tested in triplicate. Results are expressed as means (SEM) of the preparation results. Significance of differences were tested using the Student's $t$ test and were considered statistically significant if $\mathrm{p} \leqslant 0.05$.

\section{RESULTS}

Enzymatic digestion of gastric mucosal tissue resulted in the preparation of functional mouse gastric glands in terms of

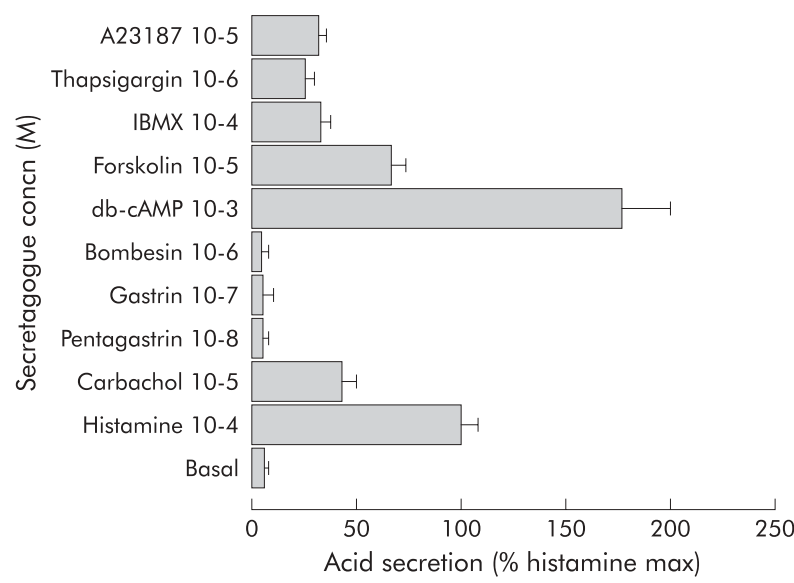

Figure 3 Effect of various secretagogues on acid secretion in the mouse gastric gland incubated for 60 minutes at $37^{\circ} \mathrm{C}$. The dose-response was constructed for each secretagogue and this figure shows concentrations at which acid secretion was the highest/maximal. Maximal effect of secretagogues on acid secretion is expressed in relation to maximal histamine stimulation (100\%) ( $n=4-7)$. IBMX, 3-isobutyl-I-methylxantine; db-cAMP, adenosine cyclic monophosphate. their ability to secrete acid for up to five hours. Nearly all cells in the glands were viable before and after one hour exposure to cytokines, as measured by trypan blue exclusion, and only some of the free floating cells appeared to be damaged (fig 1).

Initial experiments with time course indicated that 60 minutes of incubation was an optimal time to obtain a maximal response to carbachol and histamine (fig 2A). Mouse gastric glands were able to accumulate AP as a means of measuring acid secretion which could be evoked either through an adenosine cyclic monophosphate dependent mechanism (for example, histamine, forskolin, and 3-isobutyl-l-methylxantine) or calcium dependent mechanism (for example, carbachol, A23187, and thapsisgargin) (fig 3). However, gastrin and pentagastrin did not have any effect on acid secretion indicating that in the mouse, this hormone may stimulate acid only via functional enterochromaffin-like cells, most likely not prevalent in our preparation. Also, there was no increase in the histamine response in the presence of pentagastrin (data not shown). Basal and histamine stimulated AP uptake were, respectively, 2442 (653) and 41270 (15 573) dpm/mg of protein. Dose-response curves were constructed for each secretory compound and the doses that evoked the maximal response are presented in fig 3, showing a relative magnitude of the maximal response compared with histamine (100\%).

With respect to the type of receptor involved in histamine stimulation of acid secretion in the mouse, we confirmed that the histamine $\mathrm{H}_{2}$ receptor was the only type involved, as is the case in most species, including humans. Only a selective $\mathrm{H}_{2}$ receptor antagonist, ranitidine, but not other types represented here by mepyramine $\left(\mathrm{H}_{1}\right.$ selective) or thioperamide $\left(\mathrm{H}_{3}\right.$ selective $)$, inhibited histamine stimulated acid secretion (fig 2B). These findings were also confirmed in 


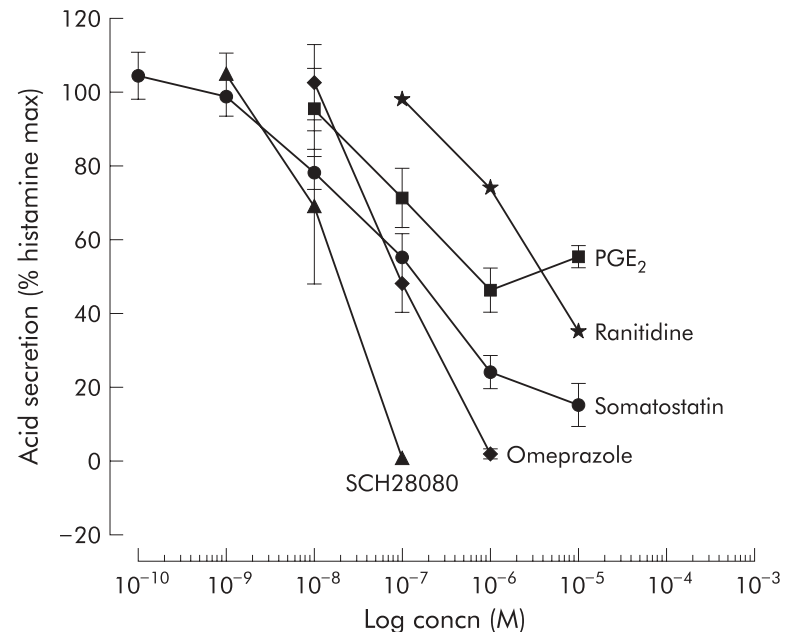

Figure 4 Inhibitory effect of various antisecretory drugs and agents on $0.1 \mathrm{mM}$ histamine stimulated acid secretion $(n=4-9)$. $\mathrm{PGE}_{2}$, prostaglandin $\mathrm{E}_{2}$.

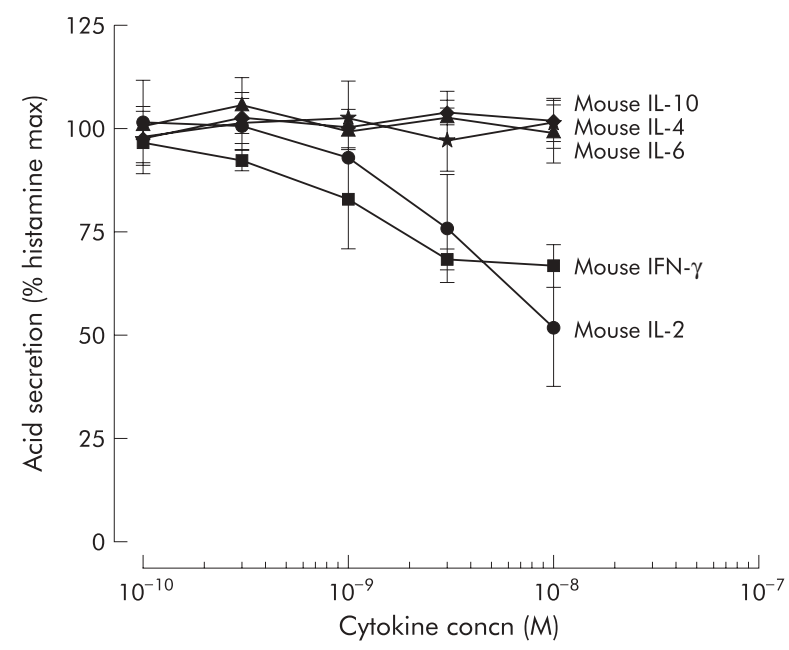

Figure 5 Inhibitory effect of the Th1 cytokines interferon $\gamma($ IFN- $\gamma)$ and interleukin 2 (IL-2) on $0.1 \mathrm{mM}$ histamine stimulated acid secretion measured by $\left[{ }^{14} \mathrm{C}\right]$ aminopyrine accumulation in mouse gastric glands $(n=4-5)$.

experiments using histamine selective agonists where only dimaprit $\left(\mathrm{H}_{2}\right.$ selective) but not PEA $\left(\mathrm{H}_{1}\right.$ selective) or $\mathrm{R}-\alpha$ methylhistamine ( $\mathrm{R}-\alpha-\mathrm{MH}, \mathrm{H}_{3}$ selective) was able to stimulate acid secretion (fig 2C) in mouse glands. The cholinergic system was similarly studied, where carbachol stimulated acid secretion was inhibited by muscarinic receptor antagonists and their potency was of the following order: atropine (non-selective) $>p$-FHHSDiF $\left(\mathrm{M}_{3}\right.$ selective) $>$ pirenzepine $\left(M_{1}\right.$ selective) $>$ AFDX-116 ( $M_{2}$ selective) (fig $\left.2 D\right)$. Therefore, predominantly the $\mathrm{M}_{3}$ muscarinic receptor is involved in carbachol stimulated acid secretion in the mouse. The two native antisecretory agents somatostatin and $\mathrm{PGE}_{2}$ inhibited histamine stimulated acid secretion, as well as the antisecretory drugs ranitidine, omeprazole, and SCH28080 (fig 4). The antisecretory compounds exhibited the following order of potency in the mouse gastric glands: SCH28080 (reversible inhibitor of acid secretion) $>\mathrm{PGE}_{2}>$ somatostatin $>$ omeprazole (irreversible proton pump inhibitor) >ranitidine (selective histamine $\mathrm{H}_{2}$ receptor agonist). Mean (SEM) $\mathrm{IC}_{50}$ values were: $1.48(0.24) \times 10^{-8} \mathrm{M}, 5.98(0.46) \times 10^{-8} \mathrm{M}, 6.99(0.20)$

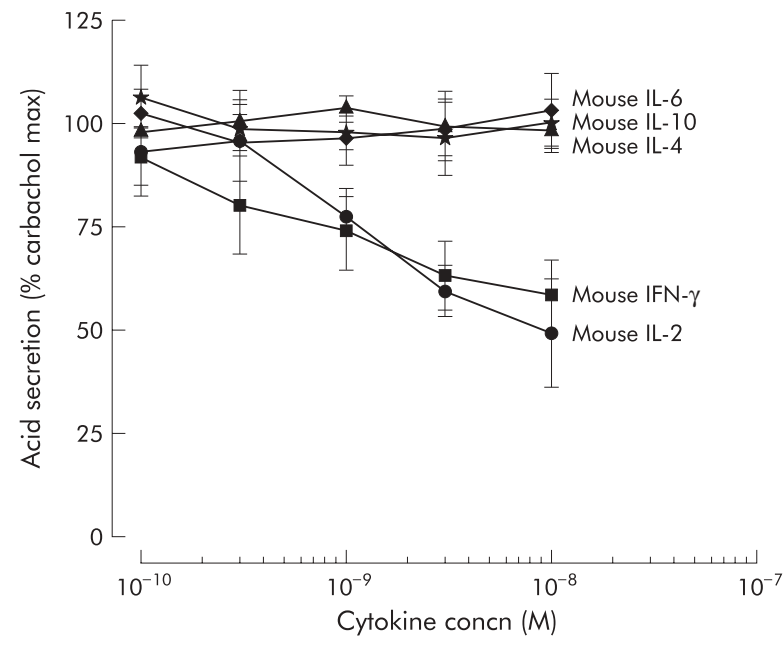

Figure 6 Inhibitory effect of Th1 cytokines interferon $\gamma($ IFN $-\gamma)$ and interleukin 2 (IL-2) on $0.01 \mathrm{mM}$ carbachol stimulated acid secretion measured by $\left[{ }^{14} \mathrm{C}\right]$ aminopyrine accumulation in mouse gastric glands $(n=4-5)$.

$\times 10^{-8} \mathrm{M}, \quad 7.16(0.09) \times 10^{-8} \mathrm{M}, \quad 1.93(0.04) \times 10^{-6} \mathrm{M}$, respectively.

Of the seven mouse cytokines tested, only IFN- $\gamma$ and IL-2 inhibited histamine stimulated acid secretion in a dose dependent manner, as measured by AP accumulation (fig 5). The maximal concentration tested for IFN- $\gamma$ was $10^{-8} \mathrm{M}$, resulting in $33 \%$ inhibition, and for IL-2, $10^{-8} \mathrm{M}$, which caused $49 \%$ inhibition. Similarly, against carbachol stimulation, only mouse IFN- $\gamma$ and IL-2 showed a dose dependent inhibition of acid secretion (fig 6).

Maximal inhibition for IFN- $\gamma$ and IL- 2 was observed at the highest doses tested, with inhibition of $42 \%$ and $53 \%$, respectively. In addition to mouse IL- $1 \beta$ and TNF- $\alpha$, the human cytokines IFN- $\gamma$, IL-1 $\beta$, IL-10, IL-4, IL-6, TNF- $\alpha$, and IL- 8 tested in the range $10^{-10} \mathrm{M}$ to $10^{-8} \mathrm{M}$ did not show any effect on histamine or carbachol stimulated acid secretion (data not shown). Mouse IFN- $\gamma$ did not cause a shift in the dose-response curves to either histamine or carbachol but only affected the maximal stimulatory response (fig 7). Preincubation of gastric glands for an additional 60 minutes with mouse IFN- $\gamma$ cytokines (alone without secretagogues and AP) did not affect significantly the reported results (fig 7). The same was true for IL-1 $\beta$ and IL-2 at the highest concentration tested $\left(10^{-8} \mathrm{M}\right)$.

The inhibitory effect of IFN- $\gamma$ was partly blocked (approximately $60 \%$ reversal of antisecretory effect of IFN- $\gamma$ ) by $1: 20$ dilution $(25 \mu \mathrm{g})$ of the rat antimouse IFN $-\gamma$ monoclonal antibody (fig 8). Non-specific, isotype control, purified rat myeloma IgGl antibody at a concentration of $25 \mu \mathrm{g}$ did not significantly alter the antisecretory properties of mouse IFN- $\gamma$ or responses to carbachol.

Endotoxin, a possible contaminant of recombinant cytokine preparations, did not have any effect on basal, carbachol, or histamine stimulated acid secretion over a wide range from $0.001 \mathrm{pg} / \mathrm{ml}$ to $10.0 \mu \mathrm{g} / \mathrm{ml}$ (data not shown).

\section{DISCUSSION}

The effect of cytokines on acid secretion has been studied principally "in vivo" and to some extent "in vitro". ${ }^{16}$ The human cytokine interleukin l (IL-1 $\beta$ ) can inhibit acid secretion "in vivo" in the $\mathrm{rat}^{17}$ but the mechanism of action of this cytokine still remains speculative and mainly attributed to its effect on the central nervous system. ${ }^{18}$ Also, inhibition of gastric histamine synthesis and release, ${ }^{19}$ and also involvement of nitric oxide, ${ }^{20}$ have been implicated in 


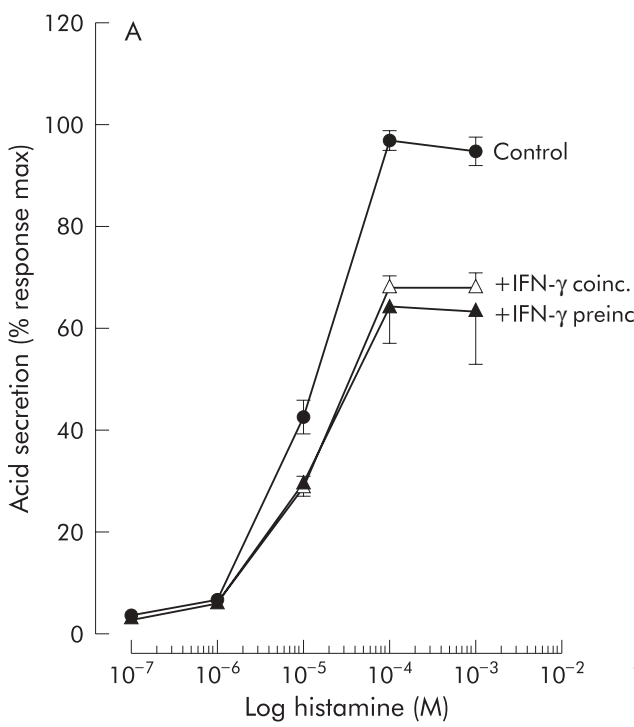

B

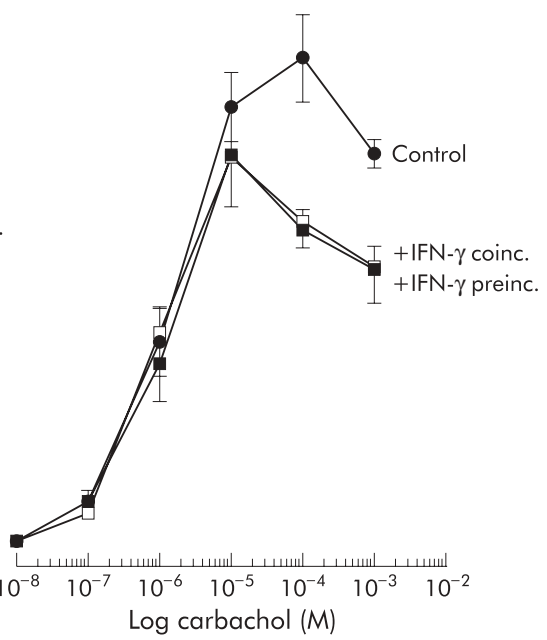

Figure 7 Effect of coincubation (coinc.) and preincubation (preinc.) of mouse gastric glands with $3 \times 10^{-9} \mathrm{M}$ interferon $\gamma$ (IFN- $\gamma$ ) on histamine (A) and carbachol (B) dose-response curves, as measured by $\left[{ }^{14} \mathrm{C}\right]$ aminopyrine accumulation $(n=3-4)$. Preincubation for 60 additional minutes with IFN- $\gamma$ was done in the absence of secretagogues and aminopyrine.

this inhibition. The antisecretory action of IL-1 can be both prostaglandin mediated ${ }^{17}{ }^{18}$ and prostaglandin independent. ${ }^{21}$ Recently, a thorough review has underscored the role of IL-1 $\beta$ in gastric pathology, in particular the importance of IL-1 $\beta$ polymorphism and consequential hyposecretion that may predispose individuals to gastric cancer. ${ }^{22}$ As observed in our results, lack of direct inhibition of acid secretion by IL- $1 \beta$ does not contradict this notion but rather suggests that this discrepancy may solely reflect species differences, especially as it mirrors the lack of reports in the published literature on the direct antisecretory effects of IL- $1 \beta$ in the mouse model. A number of reports have suggested an inhibitory effect for cytokines acting in a paracrine fashion. TNF- $\alpha$ and IL- 8 can increase the release of somatostatin from canine fundic D cells. ${ }^{23}$ IFN- $\gamma$, IL-1 $\beta$, TNF- $\alpha$, and IL-2 can stimulate gastrin release from canine, human, and rabbit antral G cells, ${ }^{24-26}$ and so too does platelet activating factor in cultured rabbit $G$

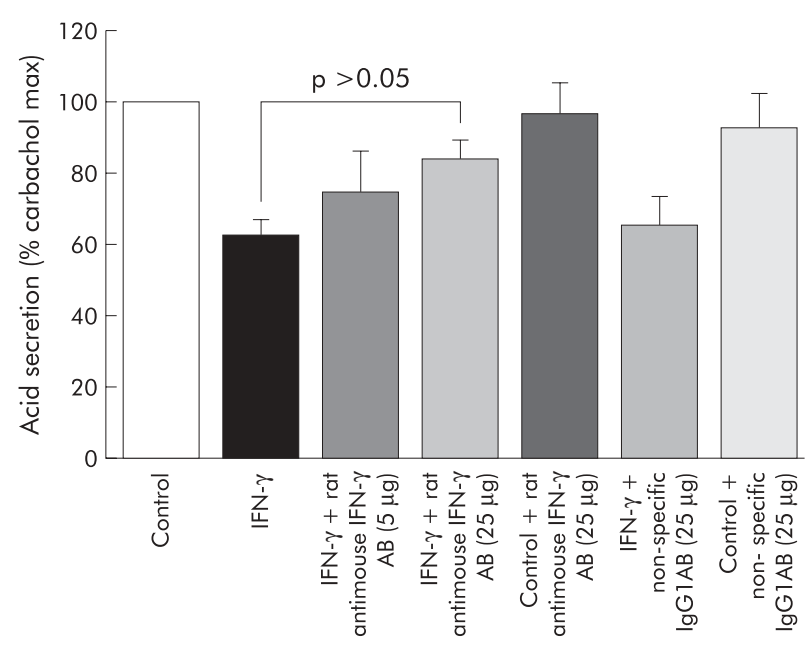

Figure 8 Reversal of the antisecretory effect of mouse interferon- $\gamma$ (IFN- $\gamma$ ) in mouse gastric glands by rat antimouse IFN- $\gamma$ monoclonal antibody (AB, 1:20 dilution of monoclonal rat antimouse IFN- $\gamma$, lg G1, or $25 \mu \mathrm{g})$. As non-specific/isotype control antibody, $25 \mu \mathrm{g}$ of purified rat myeloma, lgG1 was used. cells. ${ }^{27}$ It was not until 1994 that Nompleggi et al showed direct inhibitory effects of two cytokines, human IL- $1 \alpha$ and TNF- $\alpha$, on acid secretion, as measured by AP accumulation in canine parietal cells. ${ }^{28}$ Later, pursuing this lead, it was shown that human TNF- $\alpha$ and human IL- $1 \beta$ inhibited acid secretion in cultured rabbit parietal cells ${ }^{29}$ and when preincubated with human IL- $1 \beta$ in rat parietal cells. ${ }^{30}$ However, the most recent studies by Tani et al concluded that cytokines induced by $H$ pylori infection-namely, IL-1 $\beta$, IL-8, and TNF- $\alpha$, had no effect on acid secretion, as measured by AP accumulation in guinea pig parietal cells, which to some extent contradicted previous findings. ${ }^{31}$ It is important to point out that until now, investigators used human recombinant cytokines on systems other than human cells, such as canine, rabbit, rat, or guinea pig. As human and animal cytokines bear only partial homology and their between species cross reactivity has been demonstrated mainly in immunological systems, use of cytokines on other non-immune cells, such as parietal cells, may pose even more difficulty for interpretation of results. Mouse IL-2 and especially mouse IFN- $\gamma$ have $60 \%$ and $40 \%$ between human counterparts, respectively, which makes them highly species specific; in fact, neither show activity in human systems and human IFN- $\gamma$ does not work in the mouse.

In anticipation of this problem, we have adopted and characterised a mouse "in vitro" model of acid secretion in order to test recombinant cytokines native to the same species. The data presented here confirm the main patterns in gastric acid physiology and pharmacology in the mouse, and that the mouse gastric glands can serve as a very sensitive method for studying the involvement of native modulatory metabolites, bacterial factors, and proteins, as well as for testing antisecretory compounds. The composition of mouse gastric glands has been studied previously in intact gastric mucosa and it has been shown that approximately $20 \%$ are parietal cells, $14 \%$ zymogen cells, $47 \%$ stem cells, and $19 \%$ other cells. ${ }^{32}$ Only a moderate number of histamine containing cells were identified in mouse gastric glands, mainly at their base, and thus could possibly be injured during collagenase dispersion..$^{33}$ Pentagastrin did not have a stimulatory action on acid secretion in our studies, which supports the notion of non-functional enterochromafin-like cells in our preparation and may explain the lack of effect in our 
results with respect to IL- $1 \beta$ and TNF- $\alpha$ cytokines. However the lack of effect of these cytokines may solely reflect, as already mentioned, species differences. Our results which cover, and in some cases exceed, the range of doses tested in previous studies tend to support recent findings of the lack of such a direct effect for IL- $1 \beta$, IL- 8 , and TNF- $\alpha$, as reported by Tani and colleagues. ${ }^{31}$ Tani's results were met with criticism, but our study addressed all of these, including a comprehensive characterisation of this model with its antisecretory mediators and compounds. ${ }^{34}$

Both antisecretory cytokines IFN- $\gamma$ and IL-2 are associated with the Thl type immune response. It was shown in the mouse model of Helicobacter induced gastritis that a predominantly Thl response dominates in gastritis induced by this infection, ${ }^{35}{ }^{36}$ and that this type of response may subsequently lead to atrophy and gastric cancer. ${ }^{1937}$ Similarly, a Thl response dominates in the human gastric mucosa during $H$ pylori infection ${ }^{38}$ and a polarised Thl response may play a role in the genesis of peptic ulcer in $H$ pylori infected patients. ${ }^{39}$ Moreover, the contribution of IFN- $\gamma$ in gastric inflammation was shown to be essential in experiments with $H$ pylori infected IFN- $\gamma$ knockout mice. ${ }^{40}$ In $H$ felis infected $\mathrm{C} 57 / \mathrm{Bl} 6$ mice, coinfection with replication defective adenovirus caused, in an IFN- $\gamma$ and IL-12 dependent manner, reduced colonisation of $H$ felis but had no effect on inflammation. ${ }^{41}$ Although most of our experiments were done in Balb/c mice, we have confirmed the antisecretory effects of the highest used concentrations of mouse IL-2 and IFN- $\gamma$ on gastric glands obtained from C57/BL6 mice and therefore dismiss any strain specific differences in that regard. Recently, it has been shown that concurrent enteric helminth infection, which predominantly resulted in a reduction in IFN- $\gamma$ mRNA, attenuated Helicobacter induced gastric atrophy. ${ }^{42}$ Proposed here by us, a pivotal role of IFN- $\gamma$ in events leading to atrophy was elegantly demonstrated in mice infused with this cytokine. ${ }^{43}$ Also, our results are in line with the general understanding that the pattern of bacterial colonisation in Helicobacter infected mice is strain dependent, with $\mathrm{Balb} / \mathrm{c}$ predominantly colonising the antrum and $\mathrm{C} 57 /$ BL6 colonising the acid secreting corpus. ${ }^{44-47}$ As C57/BL6 mice respond in a Thl fashion to Helicobacter infection, our results suggest that the antisecretory properties of Thl cytokines may tip the acid related balance towards hyposecretion and colonisation by the bacterium of the corpus of the stomach. This self perpetuating process of mucosal damage may lead to atrophy, resulting in progression of inflammation and its possible consequences. These findings complement the notion that acid suppression therapy may also lead to an increase in corpus gastritis in some $H$ pylori infected patients. $^{48}$

In conclusion, our results show that mouse gastric glands can serve as a very sensitive method for studying acid secretion "in vitro". Also, we found that only the Thl specific cytokines IL-2 and IFN- $\gamma$ can inhibit acid secretion in the mouse directly, and therefore can be linked to the hyposecretion observed in Helicobacter induced gastritis that may lead to gastric atrophy and its potential serious consequences.

\section{Authors' affiliations \\ I T Padol, R H Hunt, Intestinal Disease Research Programme, McMaster University, Hamilton, Ontario, Canada}

\section{REFERENCES}

1 Blanchard TG, Czinn SJ. Review article: immunological determinants that may affect the Helicobacter pylori cancer risk. Aliment Pharmacol Ther 1998; 12(suppl 1):83-90.

2 Lee A, Dixon MF, Danon SJ, et al. Local acid production and Helicobacter pylori: a unifying hypothesis of gastroduodenal disease. Eur J Gastroenterol Hepatol 1995;7:461-5.
3 Veldhuyzen Van Zanten SJO, Dixon MF, Lee A. The gastric transitional zones: Neglected links between gastroduodenal pathology and Helicobacter ecology. Gastroenterology 1999;116:1217-29.

4 Dixon MF. Patterns of inflammation linked to ulcer disease. Best Pract Res Clin Gastroenterol 2000;14:27-40.

5 Calam J. Helicobacter pylori modulation of gastric acid. Yale J Biol Med 1999;72:195-202.

6 McColl KE, El-Omar E, Gillen D. Helicobacter pylori gastritis and gastric physiology. Gastroenterol Clin N Am 2000;29:687-703.

7 Kuipers EJ. Helicobacter pylori and the risk and management of associated diseases: gastritis, ulcer disease, atrophic gastritis and gastric cancer. Aliment Pharmacol Ther 1997;1 1:71-88.

8 Mohammadi M, Redline R, Nedrud J, et al. Role of the host in pathogenesis of Helicobacter-associated gastritis: $\mathrm{H}$. felis infection of inbred and congenic mouse strains. Infect Immun 1996;64:238-45.

9 Fox JG, Li X, Cahill RJ, et al. Hypertrophic gastropathy in Helicobacter felis infected wild-type C57BL/6 mice and p53 hemizygous transgenic mice. Gastroenterology 1996;110:155-66.

10 Lee A, O'Rourke J, Corazon de Ungria M, et al. A standardized mouse model of Helicobacter pylori infection: introducing the Sydney strain. Gastroenterology 1997;112:1386-97.

11 Padol IT, Moran AP, Hunt RH. Effect of purified lipopolysaccharides from strains of Helicobacter pylori and Helicobacter felis on gastric acid secretion in mouse gastric glands in vitro. Infect Immun 2001;69:3891-6.

12 Hinkle KL, Bane GC, Jazayeri A, et al. Enhanced calcium signaling and acid secretion in parietal cells isolated from gastrin-deficient mice. Am J Physiol Gastrointest Liver Physiol 2003;284:G145-53.

13 Berglindh T. Gastric glands and cells: preparation and in vitro methods. Methods Enzymol 1990;192:93-107.

14 Pfeiffer A, Rochlitz H, Noelke B et al. Muscarinic receptors mediating acid secretion in isolated rat gastric parietal cells are of M3 type. Gastroenterology 1990;98:218-22

15 Keeling DJ, Laing SM, Senn-Bilfinger J. SCH 28080 is a lumenally acting, $\mathrm{K}^{+}$site inhibitor of the gastric $\left(\mathrm{H}^{+}+\mathrm{K}^{+}\right)$-ATPase. Biochem Pharmacol 1988;37:2231-6.

16 Arakawa T, Watanabe T, Kobayashi K. Regulation of acid secretion and peptic ulcer formation by inflammatory cytokines. In: Ernst PB, Michetti $\mathrm{P}$, Smith PD, eds. The immunobiology of $H$. pylori: from pathogenesis to prevention. Philadelphia: Lippincott-Raven, 1997:183-99.

17 Uehara A, Okumura T, Sekiya C, et al. Interleukin-1 inhibits the secretion of gastric acid in rats: possible involvement of prostaglandin. Biochem Biophys Res Commun 1989;162:1578-84.

18 Taché Y, Saperas E. Potent inhibition of gastric acid secretion and ulcer formation by centrally and peripherially administered interleukin-1. Ann NY Acad Sci 1992;664:353-68.

19 Kondo S, Shinomura Y, Kanayama S, et al. Interleukin-1 $\beta$ inhibits gastric histamine secretion and synthesis in the rat. Am J Physiol 1994;267:G966-71.

20 Esplugues JV, Barrachina MD, Calatayud S, et al. Nitric oxide mediates the inhibition by interleukin-1 $\beta$ of pentagastrin-stimulated rat gastric acid secretion. Br J Pharmacol 1993;108:9-10.

21 Wallace JL, Cucala M, Mugridge K, et al. Secretagogue-specific effects of interleukin-1 on gastric acid secretion. Am J Physiol 1991;261:G559-64.

22 El-Omar EM. The importance of IL-1 $\beta$ in Helicobacter pylori associated disease. Gut 2001;48:743-7.

23 Beales I, Calam J, Post $L$, et al. Effect of tumor necrosis factor $\alpha$ and interleukin 8 on somatostatin release from canine fundic D cells. Gastroenterlogy 1997;112:136-43

24 Beales ILP, Post L, Calam J, et al. Tumor necrosis factor alpha stimulates release from canine and human antral $G$ cells: possible mechanism of the Helicobacter pylori-gastrin link. Eur J Clin Invest 1996:26:609-11.

25 Lehmann FS, Golodner EH, Wang J, et al. Mononuclear cells and cytokines stimulate gastric release from canine antral cells in primary culture. Am J Physiol 1996;270:G783-8.

26 Weigert N, Schaffer K, Schusdziarra V, et al. Gastrin secretion from primary cultures of rabbit antral $\mathrm{G}$ cells: stimulation by inflammatory cytokines. Gastroenterology 1996;110:147-54.

27 Beales IL. Effect of platelet-activating factor on gastrin release from cultured rabbit G-cells. Dig Dis Sci 2001;46:301-6.

28 Nompleggi DJ, Beinborn M, Roy A, et al. The effect of recombinant cytokines on $\left[{ }^{14} \mathrm{C}\right]$-aminopyrine accumulation by isolated canine parietal cells. $J$ Pharmacol Exp Ther 1994;270:440-5.

29 Beales ILP, Calam J. Interleukin $1 \beta$ and tumor necrosis factor $\alpha$ inhibit acid secretion in cultured rabbit parietal cells by multiple pathways. Gut 1998:42:227-34

30 Schepp W, Dehne K, Herrmuth $\mathrm{H}$, et al. Identification and functional importance of IL-1 receptors on rat parietal cells. Am J Physiol 1998;275:G1094-105.

31 Tani N, Watanabe Y, Suzuki T, et al. Effects of inflammatory cytokines induced by Helicobacter pylori infection on aminopyrine accumulation in parietal cells isolated from guinea pigs. Dig Dis Sci 1999;44:686-90.

32 Chen KY, Withers R. Proliferative capability of parietal and zymogen cells. $J$ Anat 1975; 120:421-32.

33 Håkanson R, Böttcher G, Ekblad E, et al. Histamine in endocrine cells in the stomach. A survey of several species using a panel of histamine antibodies. Histochemistry 1986;86:5-17.

34 Beales ILP. Effects of pro-inflammatory cytokines on acid secretion. Dig Dis Sci 2000;45:289-90.

35 Mohammadi M, Czinn S, Redline R, et al. Helicobacter-specific cell-mediated immune responses display a predominant Thl phenotype and promote 
delayed-type hypersensitivity response in the stomachs of mice. J Immunol 1996;156:4729-38

36 Mohammadi M, Nedrud J, Redline R, et al. Murine CD4 T-cell response to Helicobacter infection: Th1 cells enhance gastritis and Th2 cells reduce bacterial load. Gastroenterology 1997;113:1848-57.

37 Ruiz B, Correa P, Fontham ETH, et al. Antral atrophy, Helicobacter pylori colonization, and gastric pH. Am J Clin Pathol 1996;105:96-101.

38 Bamford KB, Fan X, Crowie SE, et al. Lymphocytes in the human gastric mucosa during Helicobacter pylori have a T helper cell 1 phenotype. Gastroenterology 1998;114:482-92.

39 D'Elios MM, Manghetti M, Almerigogna F, et al. Different cytokine profile and antigen-specificity repertoire in Helicobacter pylori-specific T cell clones from the antrum of chronic gastritis patients with or without peptic ulcer. Eur J Immunol 1997:27:1751-5.

40 Sawai N, Kita M, Kodama T, et al. Role of gamma interferon in Helicobacter pylori-induced gastric inflammatory responses in a mouse model. Infect Immun 1999:67:279-85.

41 Jiang B, Jordana M, Xing Z, et al. Replication-defective adenovirus infection reduces Helicobacter felis colonization in the mouse in a gamma interferon- and interleukin-12-dependent manner. Infect Immun 1999;67:4539-44.
42 Fox JG, Beck P, Dangler CA, et al. Concurrent enteric helminth infection modulates inflammation and gastric immune responses and reduces Helicobacter-induced gastric atrophy. Nat Med 2000;6:536-42.

43 Cui G, Hougthon J, Finkel N, et al. IFN-gamma infusion induces gastric atrophy, metaplasia and dysplasia in the absence of Helicobacter infection-a role for the immune response in Helicobacter disease. Gastoenterology 2003;124(suppl 1):A19.

44 Danon SJ, O'Rourke JL, Moss ND, et al. The importance of local acid production in the distribution of Helicobacter felis in the mouse stomach. Gastroenterology 1995;108:1386-95.

45 Sakagami T, Dixon M, O'Rourke J, et al. Atrophic gastric changes in both Helicobacter felis and Helicobacter pylori infected mice are host dependent and separate from antral gastritis. Gut 1996;39:639-48.

46 Dial EJ, Hall LR, Romero JJ, et al. Altered gastrin regulation in mice infected with Helicobacter felis. Dig Dis Sci 2000;45:1308-14.

47 Smythies LE, Waites KB, Lindsay JR, et al. Helicobacter pylori-induced mucosal inflammation is Th1 mediated and exacerbated in IL-4, but not IFN- $\gamma$ gene-deficient mice. J Immunol 2000;165:1022-9.

48 Kuipers EJ, Uyterlinde AM, Peña AS, et al. Increase of Helicobacter pyloriassociated corpus gastritis during acid suppressive therapy: implications for long-term safety. Am J Gastroenterol 1995;90:1401-6.

\section{EDITOR'S QUIZ: GI SNAPSHOT}

\section{Answer}

From question on page 1063

At laparotomy, fundal cecectomy, including appendectomy, was performed. The peritoneum was normal. The specimen consisted of a $3 \times 4 \times 9 \mathrm{~cm}$ cystic appendiceal mass with the appearance of a "chicken drumstick", filled with yellowish gelatinous mucus. The pathological diagnosis was mucinous cystadenoma.

Appendiceal mucocele, appendiceal distension with mucus, are present in approximately $0.2-0.3 \%$ of appendectomy specimens. Most patients present with appendicitis or palpable mass but asymptomatic neoplasms may be found incidentally. Appendiceal mucocele are classified histologically into several groups: retention cysts, mucosal hyperplasia without atypia, mucinous cystadenoma, and mucinous cystadenocarcinoma. Colonoscopic image of the appendiceal orifice observed in the top of the submucosal mound is called the "volcano

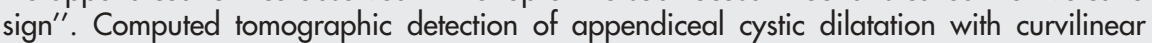
mural calcification is quite reliable for the preoperative diagnosis. These lesions should be resected because rupture of the lesion may result in pseudomyxoma peritonei. The patient recovered uneventfully and remains asymptomatic.

doi: $10.1136 /$ gut.2003.034009 